\title{
A Beaked Wormsnake, Grypotyphlops acutus (Duméril \& Bibron 1844), in the Sathyamangalam Tiger Reserve of Southern India
}

\author{
Pandi Karthik ${ }^{1}$ and Debaprasad Sengupta ${ }^{2}$
}

${ }^{1}$ Deptartment of Zoology and Wildlife Biology, A.V.C. College (Autonomous), Mannampandal - 609305, Tamil Nadu, India (karthikwildlifebiology@gmail.com) ${ }^{2}$ Wildlife Institute of India, Chandrabani, Dehradun - 248001, Uttarakhand, India

$\mathrm{T}_{\mathrm{h}}^{\mathrm{h}}$ he Beaked Wormsnake (Grypotyphlops acutus), one of the largest Asian wormsnakes (e.g., Whitaker and Captain 2004; Dasgupta et al. 2009), is endemic to peninsular India. These snakes can readily be distinguished, even by an amateur, from all other Indian scolecophidians due to their large conical bodies and distinctive head profiles (e.g., Duméril and Bibron 1844; Smith 1943; Wallach 1994). The biology and population trends of typhlopid snakes, including G. acutus, are little known (e.g., Srinivasalu et al. 2013; Hedges et al. 2014), which is largely attributable to their fossorial habits.

Wallach (1994), Dasgupta et al. (2009), Ingle (2011), Nitin et al. (2012), Bhubathy and Sathishkumar (2013), and
Pyron and Wallach (2014) considered G. acutus to be rare and unusual, although the species has been categorized as being of Least Concern on the IUCN Red List (Srinivasalu et al. 2013). We suggest that this discrepancy is a consequence of Srinivasalu et al. (2013) relying heavily on the earlier literature when, in fact, recent surveys in the known range of the species have only rarely encountered this species.

At 1230 h on 16 March 2017, during a carnivore-sign survey conducted by the World Wildlife Fund, India, we encountered an adult Beaked Wormsnake (Fig. 1) beneath a rock in Kallampalayam Beat in the Sathyamangalam Tiger

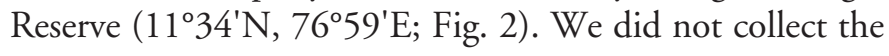

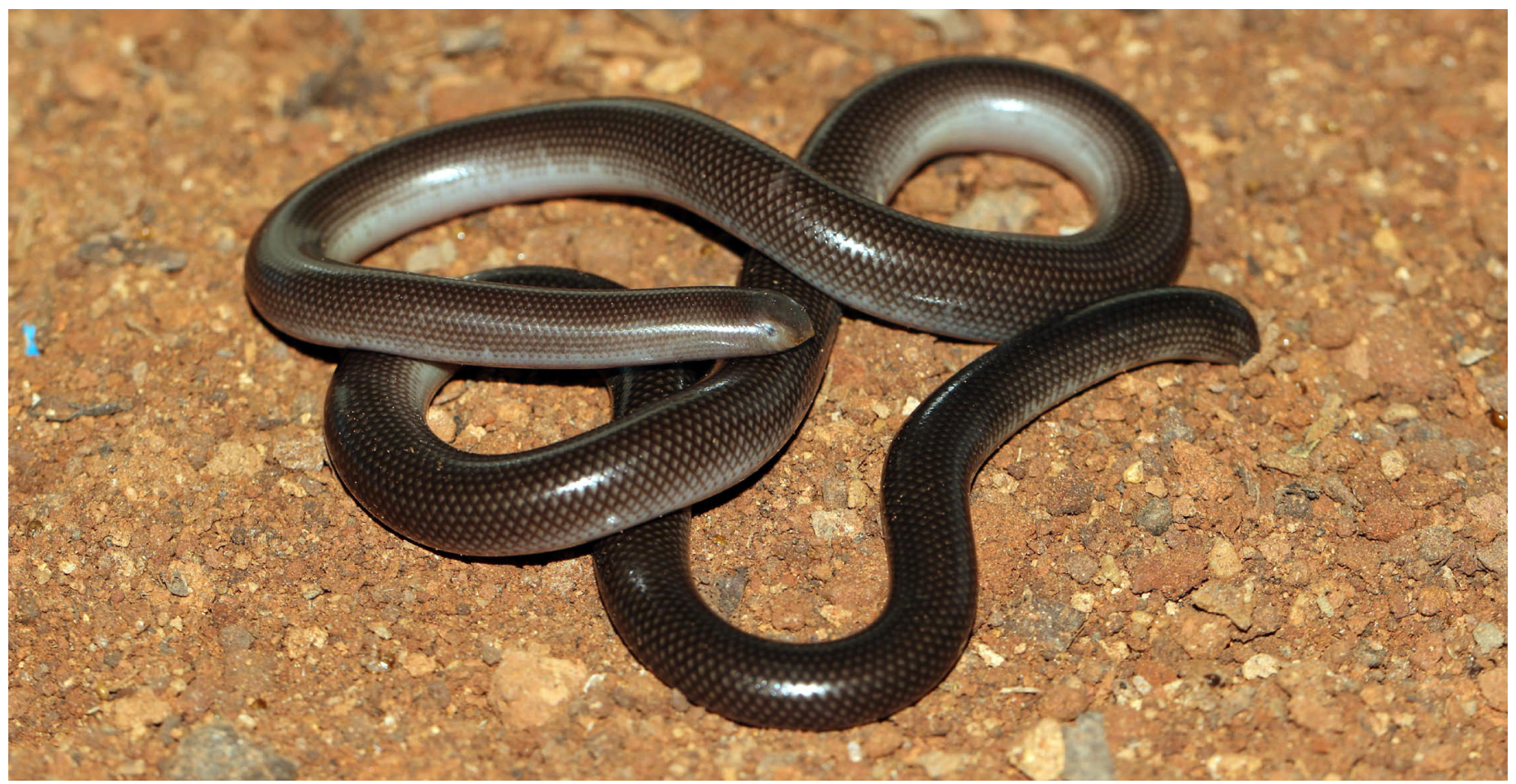

Fig. 1. The adult Beaked Wormsnake (Grypotyphlops acutus) from the Sathyamangalam Tiger Reserve in Southern India. Photograph by Ashay Khandekar. 


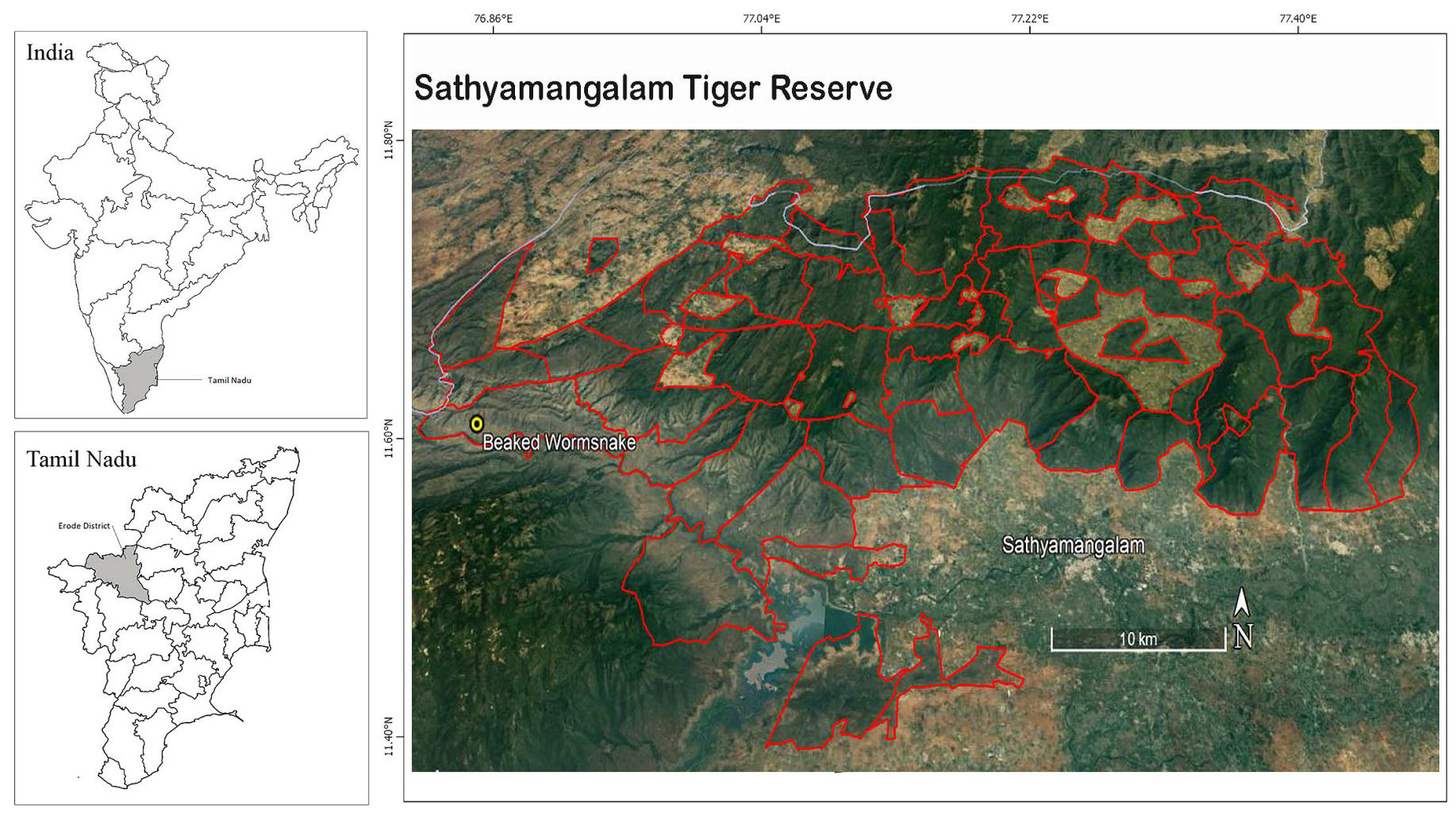

Fig. 2. A locality of a Beaked Wormsnake (Grypotyphlops acutus) in the Sathyamangalam Tiger Reserve in Southern India.

snake, which was identified on the basis of our experience with the species and the existing literature (e.g., Smith 1943; Whitaker and Captain 2004; Hedges et al. 2014). We took photographs, measurements $(\mathrm{SVL}=32.3 \mathrm{~cm}, \mathrm{TL}=0.6 \mathrm{~cm}$ ), and recorded the location $\left(11^{\circ} 34^{\prime} 26^{\prime \prime} \mathrm{N}, 76^{\circ} 52^{\prime} 54^{\prime \prime} \mathrm{E}\right.$; elev. $391 \mathrm{~m}$ asl), microhabitat (open grass land), and macrohabitat (scrub-jungle).

Due to the paucity of recent records, we believe that this species might well be in decline. Consequently, any confirmed locality records and information on natural history and conservation threats are necessary to accurately evaluate its current conservation status.

\section{Acknowledgements}

We thank Boominathan and Krishnakumar, World Wildlife Fund, India, for granting internship opportunities; our colleagues Shaheer Ali, Tamil Iniyan, and Sanan D'Souza, for assistance in the field; and the Sathyamanglam Forest Division and Ashay Khandekar for the photographs.

\section{Literature Cited}

Bhubathy, S. and N. Sathishkumar. 2013. Status of reptiles in Meghamalai and its environs, Western Ghats, Tamil Nadu, India. Journal of Threatened Taxa 5:
4953-4961.

Duméril, A.M.C. and G. Bibron. 1844. Erpétologie Générale ou Histoire Naturelle Complète des Reptiles. Tome sixième. Librairie Encyclopédique de Roret, Paris.

Dasgupta, G., R.K. Biswas, and, S. Raha. 2009. Checklist of the blind snakes (Typhlopidae), pythons and boas (Boidae) of India. Records of the Zoological Survey of India 109: 13-30.

Hedges, S.B., A.B. Marion, K.M. Lipp, J. Marin, and N. Vidal. 2014. A taxonomic framework for typhlopid snakes from the Caribbean and other regions (Reptilia, Squamata). Caribbean Herpetology 49: 1-61.

Ingle, M. 2011. Herpetofauna of Naglok Region, Jashpur District, Chhattisgarh. Records of the Zoological Survey of India 111: 79-96.

Pyron, R.A. and V. Wallach. 2014. Systematics of the blindsnakes (Serpentes: Scolecophidia: Typhlopoidea) based on molecular and morphological evidence. Zootaxa 3829: 1-81.

Srinivasulu, B., C. Srinivasalu, S.P. Vijayakumar, S.R. Ganesh, and M. Madala. 2013. Grypotyphlops acutus. IUCN Red List of Threatened Species 2013: e.T172598A1349131 (http://www.iucnredlist.org/details/172598/0).

Smith, M.A. 1943. The Fauna of British India, Ceylon and Burma, including the Whole of the Indo-Chinese Region. Vol. III. Serpentes. Taylor and Francis, London.

Nitin, W., V. Awsare, S. Karangutkar, V. Wagh, B. Yengal, and S. Salvi. 2012. Herpetofauna of Maharashtra Nature Park, Mumbai, Maharashtra (India). World Journal of Environmental Biosciences 1: 90-99.

Wallach, V. 1994. The status of the Indian endemic Typhlops acutus (Duméril \& Bibron) and the identity of Typhlops psittacus Werner (Reptilia, Serpentes, Typhlopidae). Bulletin de l'nstitut Royal des Sciences Naturelles de Belgique 64: 209-229.

Whitaker, R. and A. Captain. 2004. Snakes of India, the Field Guide. Draco Books, Chennai. 